\title{
MICROBIOLOGY IN LATIN-AMERICA
}

\begin{abstract}
THE second Latin-American and the first Costa Rica National Congresses of Microbiology were jointly held in San Jose during December 10-17, 1961. The meeting was attended by about 300 participants from 16 nations, including 50 from England, Canada and the United States.

Listed in the scientific programme were more than 150 titles, encompassing the following fields: general, medical and veterinary bacteriology; immunology; helminthology; mycology; protozoology; virology; phytopathology; and agricultural and industrial microbiology. The predominant interest was expressed in medical microbiologv. Abstracts of papers are published in a general programme and résumé, with full papers to be submitted individually through the usual scientific journals.

Special symposia or panel sessions were concerned with leishmaniasis, intestinal parasitosis, microbial physiology and biochemistry, and teaching of microbiology and parasitology. Simultaneous SpanishEnglish translation made language no barrier to effective communication in the special sessions.

Those present at the Congresses were afforded opportunity to inspect the entirely new and remarkably designed buildings comprising the University of Costa Rica. The status of microbiology in the host nation was indicated by its position as a separate College and by an impressively functional and wellequipped building in University City. A day was devoted to a trip through the mountainous countryside to the Inter-American Institute of Agricultural Science.

Among the commercial and scientific exhibits, interest was especially expressed in Revista Latinamericana de Microbiologia, an international journal of the Latin-American Microbiological Association, now in its fourth volume. Lucid abstracts are
\end{abstract}

provided in translation of the articles, which are usually in Spanish. Important for coverage in a great geographical area of microbiology, Revista is available at 6 dollars (U.S.) a year through the editor, Dr. J. M. Gutiérrez Vásquez, Escuela Nacional de Ciencias Biológicas, Instituto Politecnico Nacional, Mexico, D.F.

The programme of the Congresses incorporated well-organized social events, including a grand ball in the Latin-American manner, which, as the inaugural session, was attended by the President of the Republic, Senor Mario Echandi Jimenez.

The Congresses were supervised by an Organizing Committee of the Costa Rica Association, the secretary-general of which was Dr. John L. de Abate. Officers of the Latin-American Association were: President, Geraldo Varela; Vice-President, Renato Soto Pacheco; Secretary, Luis Palencia Franco; and Treasurer, Enriqueta Pizarro Suarez. Their counterparts in the Costa Rica Association were, respectively: Renato Soto Pacheco, Roger Bolanos, Fernando Montero-Gei, and Guillermo Monge Amador.

Newly elected officers of the Latin-American Association are: President, A. Pomales Lebron; Secretary, Jose Oliver Gonzalez; and Treasurer, Irving Fox.

The American Society for Microbiology was officially represented by Philipp Gerhardt (secretary) and R. W. Sarber (executive-secretary). Their travel was sponsored by the National Science Foundation and Difco Laboratories, Inc.

The Latin-American Congresses are convened at three-year intervals, the first in 1958 at Mexico City and the third scheduled for 1964 at a place yet to be named. It holds promise of being as stimulating and rewarding as that just concluded.

Philipp Gerhardt

\section{THE INFORMATION PROBLEM IN BIOSYSTEMATICS}

\author{
By DR. V. H. HEYWOOD \\ The Hartley Botanic Laboratories, University of Liverpool
}

\begin{abstract}
TN many branches of science to-day problems of 1 communication and dissemination of data and ideas are causing increasing concern. Progress depends in no small measure on the extent to which scientists can become informed of the work done by others so that they can build on it, or at worst not repeat it unnecessarily. Plant taxonomy is, by its very nature, largely concerned with the utilization and arrangement of published data, and has established over the centuries, and particularly in modern times, a complex series of methods and channels for its purpose of assembling, collating and presenting information. The way this is done should be compared with the facilities open to the younger discipline of plant biosystematics. For traditional taxonomy the information is dealt with at national, regional and international levels, and finds its expression in the form of lists, indexes, catalogues, revisions, Floras and the like. Individual countries usually
\end{abstract}

prepare up-to-date Floras, and through national organizations and journals arrange the collection of floristic and taxonomic data. All this tends to minimize the delay between the original publication of new information and its easy accessibility to a wider public.

Regional organizations have also been set up towards similar ends. Association pour l'Etude Taxonomique de la Flore d'Afrique Tropicale, the Flora Malesiana Foundation and the Flora Europæa Organization are examples. International co-operation is also effected through bodies such as the International Association for Plant Taxonomy, which greatly assists the work of taxonomists through its various publications such as the Index Herbariorum, Index of Collectors, Index Nominum Genericorum, Index I'ilicum, etc. It also handles the collection of information for revision of the International Code of Botanical Nomenclature. Abstracting journals and 
publications such as Index Kewensis, Fortschritle der Botanik and Excerpta Botanica are international in coverage, although all suffer from incompleteness to some extent. World surveys of various plant groups are published: the Pflanzenreich monographs, Die Natürlichen Pflanzenfamilien (second edition in course of publication); and others are projected.

The foregoing is a brief sample of the kind of facilities which are at the disposal of plant taxonom. ists. Impressive though they are, they still leavo room for improvement.

In the past 20-30 years, however, taxonomy has widenor its frontiers, and has devoted much of its efforts to investigating the nature of variation within taxonomic groups, using tho experimental garden and tho mothods of cytogenetics, and it is to cover these activities that the term 'biosystematics' is now used. Biosystematists are less concorned with the naming and description of taxa than with population genetics and cvolution. Their data often carnot be accommodated in orthodox taxonomic categorios and special terminologies havo beon proposed. Apart from some catalogues of chromosome numbers (Darlington and Wylie, Tischler, Löve and Löve, etc.) little attempt is made to systematizo biosystematic data and most of them are dispersed in scientific journals throughout the world. Abstracting systems are likewise limited, and it is worth noting that perhaps the most useful is Plant Breeding Abstracts, prepared by an 'applied' institution, the Commonwealth Bureau at Cambridge.

Biosystematics is therefore in an interesting condition: it is a new discipline and has not yet had its mothodology and results forced into a formalized straitjacket; yet the data already published are so numerous that attempts will have to be made to bring them together and make them generally available.

These and similar problems were discussed at joint meotings of Soctions 2 and 9 at tho last International Botanical Congress in Montreal in 1959. It was initially proposed that the International Union of Biological Sciences set up a committee to considor biosystematic terminology and related problems, and report back to the next Congress. As a result the International Association for Plant Taxonomy, which is the branch for plant taxonomy of tho International Union, nominated a committee for biosystematic terminology (Taxon, 9, 88; 1960).
This committeo met in Copenhagen in 1960 to discuss ways and means of collecting data; but it soon became obvious that there was a noed for an organization to promote rescarch and communication in biosystematies on an international basis. Following on discussions with the International Union for Plant Taxonomy, the International Organization of Biosystematists was founded with the following executive: A. Löve (Montreal) president; $\mathbf{T}$. W. Böcher (Copenhagen), vice-president; V. H. Hoywood (Liverpool), secretary-general; C. Favarger (Neuchâtel); W. Gajewski (Kraków); B. Lövkvist (Lund); H. Lewis (Los Angeles); H. Merxmüller (München); D. H. Valentine (Durham). Initially, the International Organization of Biosystematists will not be a fully independent organization but will require that its members be also members of the International Association for Plant Taxonomy. This arrangement will, it is hoped, be mutually beneficial.

Biosystematics is interpreted fairly broadly so as to cover such topics as genecology, oxporimental taxonomy, cytotaxonomy, micro-cvolutionary studies and speciation, not only in flowering plants but also in all other groups of the plant kingdom.

Much work relevant to biosystematics is carried out by autecologists, devolopmental physiologists and applied biologists such as foresters, pharmacologists and agronomists. The International Organization of Biosystematists hopes to provide a forum for all these workers in diverse fields and bring them into much closer contact than at present.

The initial activities of the organization were planned at a short meeting of the Executive Com. mittee held at the Institut do Botanique, Universite de Neuchatel, at the invitation of Prof. C. Favarger (Taxon, December 1961). As a result of the discussions three schemes have beon put in hand: (1) the establishment of a registration centre for the assembly and dissemination of biosystematic data; (2) the establishment of a systom to facilitate the acquisition of plant material for biosystematic research; (3) the preparation of a biosystematic glossary.

An ever-expanding stream of biosystematic in. formation is being published, and it is hoped that before it becomes a flood some efforts will have bcen made through the International Organization of Biosystematists to deal with it in the most useful manner possible.

\section{TRAINING IN OCEANOGRAPHY}

\begin{abstract}
A $\mathbf{S}$ long ago as 1955, in order to start a marine sciences programme, Unesco established an International Advisory Committes with a member ship from all parts of the world and a competence in all aspects of the subject.

The declared intention was to cultivate interest in the occans, particularly in countries where, for various reasons, little activity in marine research had been possible or was being displayed. Once funds had become availablo, the wise decision was made to stago Unesco training courses in the marine sciences from time to time in regions backward in occanogriphy. If this were done, not only would the seeds be sown so to speak; tho tutors would also be ablo to select the men most worthy of Unosco fellowships. The expected outcome would be that, with the pro-
\end{abstract}

gross of time, more and more regions would come to possess their own competent teachers.

Developments havo been along these lines. 'lowards the end of 1958 the South Asia Science Co-operation Offico of Unesco (Delhi) arranged a Refresher Course in Marine Biology at Bombay in concert with the Institute of Science of the University there.

A ycar later, a regional training course was held at the Institut Océanographique, Nhatrang, in the Republic of Vietnam. This, under the sponsorship of tho Unosco Science Co-operation Offico for South. cast Asia (Djakarta), was warmly welcomed and greatly helped by tho host Government. 'The Nhatrang courso, which was attended by twenty-four trainees, lasted for about four months. 